\title{
Pengaruh Medication Therapy Management (MTM) terhadap Tingkat Pengetahuan dan Kualitas Hidup Pasien Diabetes Melitus Di Puskesmas Kota Yogyakarta
}

\author{
The Effect of Medication Therapy Management (MTM) on Diabetic \\ Patients' Knowledge and Quality of Life in Yogyakarta Public Health \\ Center
}

\author{
Nita Trinovitasari ${ }^{1}$, Nanang Munif Yasin ${ }^{2}$, Chairun Wiedyaningsih ${ }^{2}$ \\ ${ }^{1}$ Magister Farmasi Klinik, Fakultas Farmasi, Universitas Gadjah Mada \\ 2 Fakultas Farmasi, Universitas Gadjah Mada \\ email: nita.trinovitasari@gmail.com, nanangy@yahoo.com \\ (tanggal diterima: 05-08-2020, tanggal disetujui: 04-11-2020)
}

\section{INTISARI}

Masalah yang sering terjadi pada pasien diabetes adalah kurangnya pengetahuan terkait pengobatan dan penyakitnya. Hal tersebut diketahui akan menjadi hambatan dalam pelaksanaan terapi yang pada akhirnya akan berdampak pada ketidak optimalan terapi dan penurunan kualitas hidup. Permasalahan ini dapat diatasi dengan memberikan edukasi kepada pasien secara kolaboratif dan kontinu. Salah satu bentuk intervensi yang dapat dilakukan adalah pelayanan Medication Therapy Management (MTM). MTM merupakan suatu layanan yang bertujuan untuk mengoptimalkan hasil terapi pasien. Pelayanan yang belum lama dilaksanakan ini memiliki elemen yang cukup banyak. Sehingga pada penelitian ini dilakukan modifikasi MTM yang diacu dari pelayanan MTM BPJS (Badan Penyelenggara Jaminan Sosial) Kesehatan. Penelitian ini bertujuan untuk mengetahui pengaruh pelayanan MTM terhadap tingkat pengetahuan dan kualitas hidup pasien diabetes melitus di Puskesmas Kota Yogyakarta.

Metode penelitian yang digunakan adalah quasi-experimental one-group design with pretestposttest design yang dilakukan pada bulan Maret hingga April 2020. Metode pengambilan sampel menggunakan teknik purposive sampling. Intervensi MTM yang diberikan dalam penelitian ini berupa asesmen, konseling, dan edukasi yang dibantu dengan menggunakan buku dokumentasi pasien dan apoteker. Penelitian ini menggunakan kuesioner sebagai instrumen penelitian. Data dianalisis dengan menggunakan SPSS.

Hasil penelitian menemukan bahwa terjadi peningkatan pengetahuan pasien dari 8,9 $\pm 2,3$ menjadi 11,6 \pm 1,5 setelah diberikan pelayanan MTM dengan nilai $\mathrm{p}=0,000$ dan terjadi peningkatan kualitas hidup pasien dari 50,56 $\pm 3,9$ menjadi 52,84 $\pm 4,3$ dengan nilai $p=0,003$. Kesimpulan penelitian ini adalah pelayanan MTM dari apoteker dapat meningkatkan pengetahuan dan kualitas hidup pasien diabetes.

Kata kunci: Diabetes Melitus, Medication Therapy Management, Tingkat Pengetahuan, Kualitas Hidup

\section{ABSTRACT}

The problem that often occurs in diabetes patients is a lack of knowledge regarding treatment and disease. It is known that things will become an obstacle in the implementation of therapy which in turn will have an impact on not optimal therapy and decrease quality of life. This problem can be overcome by providing education to patients collaboratively and continuously. One intervention that can be done is the Medication Therapy Management (MTM) service. MTM is a service that aims to optimize patient therapy outcomes. This recently implemented service has quite a several elements. So, this study modifies MTM service referenced from the MTM BPJS (Social 
Security Administering Body). This study aims to determine the effect of MTM services to the level of knowledge and quality of life on diabetes mellitus patients in Yogyakarta Public Health Center.

The employed research method was quasi-experimental one-group design with pretestposttest design and experiments were conducted in March to April 2020. The sampling method uses a purposive sampling technique. The MTM interventions provided in this study were in the form of assessment, counseling, and education assisted by using patient and pharmacist documentation books. This study uses a questionnaire as a research instrument. Data were analyzed using SPSS.

Results show a slight increase in the patients' knowledge from $8.9 \pm 2.3$ to $11.6 \pm 1.5$ after MTM services were given with p-value of 0.000 , and a slight increase in the quality of life of patients from $50.56 \pm 3.9$ to $52.84 \pm 4.3$ with a $p$-value of 0.003 . In conclusion, the MTM-based services from pharmacists can significantly increase the knowledge and quality of life of diabetic patients.

Keyword: Diabetes Mellitus, Medication Therapy Management, Level of Knowledge, Quality of Life

\section{PENDAHULUAN}

Penyakit kronis yang banyak terjadi saat ini salah satunya adalah diabetes melitus. Diabetes melitus (DM) merupakan suatu gangguan kronik yang disebabkan karena berkurangnya sekresi atau sensitifitas insulin secara absolut ataupun relatif. Gangguan ini menyebabkan terjadinya hiperglikemia, serta perubahan metabolisme lipid dan protein $(1,2)$.

Berdasarkan data dari WHO, hingga saat ini terdapat sebanyak 422 juta jiwa pengidap diabetes di dunia dengan angka kematian sebesar 1,6 juta jiwa setiap tahunnya (3). Di Indonesia, pada tahun 2016 sebesar 7\% dari populasi mengidap diabetes dengan prosentase kematian sebesar 6\% (4). Berdasarkan hasil riset kesehatan dasar tahun 2018 prevalensi penyakit DM provinsi Daerah Istimewa Yogyakarta menempati urutan kedua terbesar (5).

Masalah yang sering terjadi pada pasien DM adalah kurangnya pemahaman terkait penyakit serta pengetahuan tentang pengobatan yang dijalani. Hal tersebut diketahui akan menjadi hambatan dalam pelaksanaan terapi yang pada akhirnya akan berdampak pada ketidak optimalan terapi dan penurunan kualitas hidup $(6,7)$. Penelitian Pinto et al., (2014) menemukan bahwa peningkatan pengetahuan pasien menurunkan kejadian hipoglikemia yang menyebabkan pasien masuk UGD dan meningkatkan tercapainya target gula darah pasien, yang pada akhirnya memberikan dampak terjadinya peningkatan kualitas hidup pasien (8). Permasalahan ini dapat diatasi dengan memberikan edukasi kepada pasien secara kolaboratif dan kontinu dari tenaga kesehatan.

Salah satu bentuk intervensi yang dapat dilakukan tersebut adalah pelayanan Medication Therapy Management (MTM). MTM merupakan suatu layanan atau program yang bertujuan untuk mengoptimalkan hasil terapi setiap pasien. Kolaborasi dari semua tenaga kesehatan dibutuhkan untuk memastikan bahwa pasien memahami kondisi kesehatannya, risiko penyakit, hasil diagnosa, serta tujuan terapi yang dijalani. Apoteker berada dalam posisi utama untuk memastikan keberhasilan kolaborasi karena aksesibilitas mereka kepada pasien dan dokter $(9,10)$. Model pelayanan MTM dalam praktek kefarmasian mencakup 5 elemen yaitu Medication Therapy Review (MTR) yang merupakan proses sistematis untuk mengumpulkan informasi spesifik pasien, menilai terapi, mengidentifikasi masalah 
aktual dan potensial terkait obat, menyusun daftar masalah yang diprioritaskan, dan membuat rencana untuk menyelesaikannya; Personal Medication Record (PMR) yang merupakan catatan komprehensif dari terapi pasien; Medication-related Action Plan (MAP) merupakan dokumen yang berisi daftar tindakan yang dapat dilakukan pasien untuk mengetahui kemajuan terapi sebagai self-management; Interventtion and/or referral adalah tahap dimana apoteker memberikan layanan konsultasi dan intervensi untuk mengatasi masalah terkait obat, serta merujuk pasien ke dokter atau profesional kesehatan lainnya bila dibutuhkan; Documentation and Follow-up yang merupakan pencatatan dan peninjauan kembali semua kegiatan atau tindakan terhadap pasien $(11,12)$.

Pelayanan berbasis MTM diharapkan dapat membantu profesional kesehatan berkoordinasi dengan baik dalam menangani pasien. Pelayanan berbasis MTM ini melibatkan peran aktif pasien dalam mengelola kesehatannya sendiri. Pasien diberikan edukasi terkait penyakit dan pengobatannya, kartu catatan pengobatan yang disimpan oleh apoteker dan pasien.

Pemerintah bersama dengan BPJS (Badan Penyelenggara Jaminan Sosial) kesehatan saat ini mencanangkan pelayanan MTM untuk dilaksanakan di pelayanan kesehatan tingkat satu. Pelayanan yang belum lama dilaksanakan ini memiliki elemen yang cukup banyak dan memakan waktu dalam pelaksanaannya (13). Belum adanya penelitian terkait pelayanan MTM di Yogyakarta mendasari penelitian ini untuk dilaksanakan. Sehingga pada penelitian ini intervensi pelayanan berbasis MTM yang dilakukan merupakan modifikasi yang disesuaikan dengan keadaan yang ada di puskesmas yang diacu dari pelayanan MTM yang dibuat oleh BPJS Kesehatan. Adanya pelayanan berbasis MTM ini diharapkan dapat meningkatkan tingkat pengetahuan pasien akan kondisi penyakit dan pengobatannya, sehingga terjadi peningkatan kualitas hidup pasien.

\section{METODE PENELITIAN}

\subsection{RANCANGAN PENELITIAN}

Penelitian ini merupakan penelitian observasional dengan rancangan quasiexperimental one-group design with pretest-posttest design. Penelitian ini digunakan untuk menganalisis pengaruh antara variabel bebas yaitu pelayanan kefarmasian berbasis medication therapy management dengan variabel terikat yaitu tingkat pengetahuan dan kualitas hidup pasien diabetes melitus di Puskesmas Kota Yogyakarta pada periode penelitian Maret - April 2020. Penelitian ini telah memperoleh izin Komisi Etik Penelitian Kesehatan Fakultas Kedokteran Universitas Gadjah Mada dengan No: KE/FK/0710/EC496/EC/2019.

\subsection{PENGUMPULAN DATA}

Metode pengambilan sampel menggunakan teknik non-random dengan cara purposive sampling yaitu teknik pengambilan sampel yang ditentukan oleh peneliti atas pertimbangan tertentu (sesuai dengan kriteria inklusi dan eksklusi yang telah ditentukan). Kriteria inklusi penelitian ini adalah pasien yang terdiagnosa diabetes melitus dengan usia $\geq 18$ tahun yang menjalani kontrol rutin minimal 1 bulan 
sebelum penelitian dilakukan dan bersedia menjadi subyek penelitian (menandatangani informed consent). Pasien yang mengalami gangguan kognitif dan tidak dapat berkomunikasi dengan baik, serta tidak menyelesaikan kuesioner dieksklusi dari penelitian ini. Penelitian ini menggunakan kuesioner sebagai instrumen penelitian. Kuesioner yang digunakan pada penlitian ini adalah DKT (Diabetes Knowledge Scale) untuk mengukur tingkat pengetahuan pasien diabetes dan DQOL (Diabetes Quality of Life) untuk mengukur kualitas hidup pasien diabetes.

\subsection{INSTRUMEN PENELITIAN Tingkat Pengetahuan}

Kuesioner Diabetes Knowledge Test (DKT) merupakan suatu kuesioner yang terdiri dari 23 item tes pengetahuan yang dikembangkan oleh Michigan Diabetes Research Training Center (MDRC). Pada tahun 2011 kuesioner ini dimodifikasi dengan bentuk jawaban benar salah dan berkurang menjadi 20 item pertanyaan. Kuesioner Diabetes Knowledge Test yang digunakan pada penelitian ini merupakan kuesioner yang telah dimodifikasi menjadi 18 item pertanyaan. Modifikasi yang dilakukan adalah mengurangi 2 buah pertanyaan bagi pasien yang menggunakan insulin. Penilaian pengetahuan pasien dilakukan dengan menjumlahkan jawaban benar. Nilai 1 untuk jawaban yang benar dan 0 untuk jawaban yang salah. Hasil penilaian dibagi menjadi 3 kelompok. Kelompok tersebut meliputi kelompok pasien pengetahuan rendah dengan skor 0-6, pengetahuan sedang dengan skor 7-12, dan pengetahuan tinggi dengan nilai 14-18. Kuisioner ini merupakan kuisioner yang reliabel dengan nilai Cronbach's alfa 0.71 dan merupakan kuisioner yang valid $(14,15)$.

\section{Kualitas Hidup}

Kuesioner DQOL (Diabetes Quality of Life) merupakan instrumen yang diterbitkan pada tahun 1988 oleh Diabetes Control and Complications Trial (DCCT) dengan 46 item pertanyaan. Penelitian Bujang dkk., tahun 2018 berhasil mengembangkan kuesioner DQOL dengan 13 item pertanyaan. Pembagian item pertanyaan pada masing - masing domain adalah 6 item pertanyaan untuk domain satisfaction (kepuasan), 4 item pertanyaan untuk domain impact (dampak), dan 3 item pertanyaan untuk domain worry (kekhawatiran). Secara keseluruhan kuesioner DQOL memiliki rentang nilai 13-65. Semakin tinggi nilai hasil kuesioner yang didapatkan maka semakin tinggi kualitas hidup pasien tersebut. Penelitian Bujang dkk., tahun 2018 menilai reliabilitas masing-masing domain adalah 0,92 (satisfaction), 0,78 (impact) dan 0,79 (worry) dengan nilai alfa $\geq 0.70$ dan merupakan kuisioner yang valid (16).

\subsection{JALANNYA PENELITIAN}

Penelitian ini dimulai dengan melakukan FGD (Focus Group Discussion) kepada Apoteker puskesmas Tegalrejo, Jetis, dan Gedongtengen kota Yogyakarta. FGD yang dilakukan ini merupakan bentuk pelatihan yang diberikan untuk 
menyamakan pelayanan berbasis MTM yang akan diaplikasikan. MTM pada penelitian ini dibagi menjadi asesmen, konseling dan edukasi yang diberikan apoteker kepada pasien. Asesmen mencakup elemen medication therapy review dan elemen personal medication record yang diimplementasikan dengan mengumpulkan informasi terkait masalah pengobatan pasien dan memberikan buku dokumentasi kepada pasien yang dibawa setiap kali kontrol oleh apoteker puskesmas. Konseling dan edukasi mencakup elemen medication-related action plan, elemen intervention, dan elemen documentation and follow-up yang diimplementasikan dengan edukasi dan konsultasi pada saat penyerahan obat, pemberian edukasi terkait diabetes dalam bentuk leaflet, dan tindak lanjut terhadap permasalahan terkait pengobatan yang didokumentasikan dalam buku apoteker. Edukasi dengan menggunakan leaflet dilakukan sebanyak 2 kali. Pertama dilakukan oleh peneliti setelah menanyakan kesediaan pasien untuk mengikuti penelitian dan yang kedua oleh apoteker puskesmas saat penyerahan obat. Satu minggu setelah FGD dilakukan pengambilan data dengan menggunakan kuesioner DKT dan DQOL dan intervensi kepada pasien. Pengambilan data dengan kuesioner dilakukan sebanyak 2 kali, yaitu sebelum MTM sebagai data pretest dan setelah 1 bulan pemberian pelayanan MTM sebagai data posttest. Sebelum dilakukan MTM oleh apoteker, pasien terlebih dahulu menandatangani informed consent dan mengisi data demografi.

\subsection{ANALISIS DATA}

Analisis pengaruh pelayanan kefarmasian berbasis MTM terhadap tingkat pengetahuan dan kualitas hidup sebelum dan setelah intervensi dilakukan dengan menggunakan analisis bivariat dependent sample T-test dan Wilcoxon test. Analisis pengaruh variabel terhadap perubahan pengetahuan dan kualitas hidup pasien dilakukan dengan menggunakan analisis bivariat independent sample T-test dan Kruskal-Wallis test.

\section{HASIL DAN PEMBAHASAN}

\subsection{Karakteristik Responden}

Bedasarkan pengambilan sampel pasien diabetes yang dilakukan pada bulan Maret hingga April 2020 di Puskesmas Tegalrejo, Jetis, dan Gedongtengen, diperoleh sebanyak 25 pasien diabetes yang memenuhi kriteria inklusi dan eksklusi. Pada tabel 1 dapat dilihat karakteristik pasien yang diikut sertakan dalam penelitian ini. Jumlah pasien dengan jenis kelamin laki - laki pada penelitian ini lebih banyak dibandingkan dengan jenis kelamin perempuan yaitu sebanyak 52\%. Berdasarkan Diabetes Care dari American Diabetes Association (ADA) jenis kelamin laki - laki memiliki risiko lebih besar untuk mengalami diabetes dibandingkan dengan perempuan (17). Pasien dengan usia lanjut 65 - 74 tahun memiliki persentase paling tinggi dalam penelitian ini yaitu 44\%. Usia memiliki peranan yang penting pada penyakit diabetes, semakin tua usia seseorang maka akan semakin tinggi risiko peningkatan kadar gula darah dan gangguan toleransi glukosa. Proses penuaan menyebabkan penurunan fungsi organ, salah satunya pankreas (sel- $\beta$ ) dalam memproduksi insulin (18). Profil tingkat pendidikan pasien dari yang terbanyak 
yaitu SMA 36\%, SMP 32\%, Universitas 24\%, dan SD 8\%. Jumlah pasien yang bekerja sebanyak 56\%. Durasi penyakit diabetes pasien yang paling banyak adalah 1 hingga 10 tahun sebanyak $60 \%$ dan yang terendah adalah $>20$ tahun sebanyak $8 \%$.

Tabel 1. Gambaran Karakteristik Pasien

\begin{tabular}{|c|c|c|}
\hline $\begin{array}{r}\text { Karakteristik } \\
\end{array}$ & Jumlah $(n=25)$ & Persentase $(\%)$ \\
\hline \multicolumn{3}{|l|}{ Jenis Kelamin } \\
\hline Laki - Laki & 13 & 52 \\
\hline Perempuan & 12 & 48 \\
\hline \multicolumn{3}{|l|}{ Usia } \\
\hline $45-54$ tahun & 5 & 20 \\
\hline $55-64$ tahun & 9 & 36 \\
\hline $65-74$ tahun & 11 & 44 \\
\hline \multicolumn{3}{|l|}{ Tingkat Pendidikan } \\
\hline $\mathrm{SD}$ & 2 & 8 \\
\hline SMP & 8 & 32 \\
\hline SMA & 9 & 36 \\
\hline UNIVERSITAS & 6 & 24 \\
\hline \multicolumn{3}{|l|}{ Pekerjaan } \\
\hline Bekerja & 14 & 56 \\
\hline Tidak Bekerja & 11 & 44 \\
\hline \multicolumn{3}{|l|}{ Durasi Penyakit } \\
\hline$<1$ tahun & 5 & 20 \\
\hline $1-10$ tahun & 15 & 60 \\
\hline 11- 20 tahun & 3 & 12 \\
\hline$>20$ tahun & 2 & 8 \\
\hline \multicolumn{3}{|l|}{ Penyakit Penyerta } \\
\hline Hipertensi & 13 & 52 \\
\hline Hiperlipidemia & 4 & 16 \\
\hline Hipertensi + Hiperlipidemia & 2 & 8 \\
\hline Tanpa Penyakit Penyerta & 6 & 24 \\
\hline \multicolumn{3}{|l|}{ Obat Yang Digunakan } \\
\hline Metformin & 13 & 52 \\
\hline Glimepirid & 1 & 4 \\
\hline Metformin + Glimepirid & 11 & 44 \\
\hline \multicolumn{3}{|l|}{ Jarak Rumah Ke Puskesmas } \\
\hline$<1 \mathrm{~km}$ & 16 & 64 \\
\hline$>1 \mathrm{~km}$ & 9 & 36 \\
\hline \multicolumn{3}{|l|}{ Status Pernikahan } \\
\hline Menikah & 14 & 56 \\
\hline Janda/Duda & 11 & 44 \\
\hline
\end{tabular}

Penyakit penyerta pasien terbanyak yaitu pasien yang memiliki hipertensi sebanyak 52\%. Menurut Rosyada dan Trihandini (2013) penyakit penyerta yang paling banyak dialami oleh pasien DM merupakan hipertensi (19). Hipertensi merupakan salah satu penyakit penyerta yang dapat berkontribusi dalam terjadinya resistensi insulin. Selain itu menurut ADA tekanan darah yang tinggi merupakan salah satu faktor risiko dari diabetes melitus $(17,18)$. Meskipun demikian mekanisme yang menghubungkan kejadian hipertensi berkontribusi dalam 
penyakit diabetes hingga saat ini masih belum jelas. Profil penggunaan obat diabetes pasien yaitu 52\% menggunakan metformin tunggal. Penggunaan obat ini sudah sesuai dengan tatalaksana yang dianjurkan oleh pemerintah berdasarkan PERKENI dalam pedoman pengelolaan dan pencegahan diabetes melitus. Berdasarkan pedoman tatalaksana tersebut metformin menjadi obat pilihan pertama yang digunakan. Metformin memiliki mekanisme menurunkan produksi glukosa di hati dan meningkatkan sensitivitas insulin.

\subsection{Pengaruh Pelayanan Berbasis MTM terhadap Pengetahuan}

Penelitian ini bertujuan untuk melihat pengaruh pelayanan berbasis MTM terhadap pengetahuan dan kualitas hidup pasien diabetes. Dilakukannya pelayanan berbasis MTM oleh apoteker puskesmas ini diharapkan dapat meningkatkan pengetahuan pasien akan penyakit dan pengobatannya. Peningkatan pengetahuan pasien akan berdampak pada optimalnya terapi. Pengukuran pengetahuan dengan kuesioner DKT akan menggambarkan tingkat pengetahuan dan pengaruh pemberian MTM terhadap pengetahuan pasien. Hasil dari pengukuran tingkat pengetahuan dan perubahan pengetahuan sebelum dan setelah pemberian pelayanan berbasis MTM dapat dilihat pada tabel 2.

Tabel 2. Pengaruh MTM terhadap Pengetahuan Pasien Diabetes Melitus

\begin{tabular}{|c|c|c|c|c|c|c|c|}
\hline $\begin{array}{c}\text { Kategori } \\
\text { Pengetahuan }\end{array}$ & $\begin{array}{l}\text { Jumlah } \\
\text { Subjek }\end{array}$ & Rendah & Sedang & Tinggi & $\begin{array}{c}\text { Rata - Rata } \\
\text { Skor } \pm \text { SD }\end{array}$ & CI 95\% & Nilai P \\
\hline Pretest & 25 & 3 & 20 & 2 & $8,9 \pm 2,3$ & \multirow[t]{2}{*}{$3,48-1,88$} & \multirow[t]{2}{*}{$0,000^{*}$} \\
\hline Postest & 25 & 0 & 18 & 7 & $11,6 \pm 1,5$ & & \\
\hline
\end{tabular}

Keterangan: *diuji dengan dependent sample T-test

Pada tabel 2 dapat dilihat bahwa pelayanan berbasis MTM memiliki pengaruh terhadap skor pengetahuan pasien diabetes. Pasien dengan skor pengetahuan dengan kategori tinggi berdasarkan DKT yang awalnya berjumlah 2 pasien meningkat menjadi 7 pasien. Pasien dengan skor sedang yang awalnya berjumlah 20 pasien turun menjadi 18 pasien. Pasien dengan skor rendah yang awalnya berjumlah 3 pasien turun menjadi 0 pasien. Masih terdapat pasien yang memiliki skor pengetahuan sedang sebanyak 18 pasien ini dapat disebabkan karena durasi penelitian yang hanya 1 bulan lamanya. Berdasarkan rata - rata skor pengetahuan sebelum $(8,9 \pm 2,3)$ dan setelah $(11,6 \pm 1,5)$ kedua nilai tersebut masih termasuk dalam kategori pengetahuan sedang. Hanya saja berdasarkan nilai $\mathrm{p}=$ $0,000(p<0,05)$ secara statistik perbedaan skor sebelum dan setelah intervensi ini bermakna. Berdasarkan hasil ini dapat dilihat bahwa pelayanan berbasis MTM dapat meningkatkan pengetahuan pasien diabetes melitus secara bermakna. Hasil ini sejalan dengan hasil penelitian Ndefo et al., tahun 2017 terhadap 37 pasien diabetes. Penelitian tersebut menjelaskan bahwa rata - rata skor pengetahuan pasien diabetes meningkat dari 8,47 sebelum diberikan pelayanan berbasis MTM menjadi 9,57 setelah mendapatkan pelayanan berbasis MTM dengan nilai maksimal 10 (20). Perubahan tingkat pengetahuan setelah pemberian intervensi MTM juga ditemukan dalam penelitian Boban dkk., tahun 2017 terhadap 104 pasien diabetes 
dengan nilai $\mathrm{p}<0,05$. Secara statistik terdapat perbaikan tingkat pengetahuan secara bermakna setelah pemberian pelayanan MTM (21).

Adanya hasil yang positif dari pelayanan berbasis MTM ini menunjukkan bahwa kolaborasi antara tenaga medis dan peran aktif pasien dapat meningkatkan pengetahuan pasien. Diharapkan pelayanan ini dapat terus dilaksanakan untuk mengoptimalkan terapi pasien. Pengetahuan pasien yang kurang mengenai penyakit dan pengobatannya dapat menjadi hambatan dalam pelaksanaan terapi. Selain itu ada beberapa faktor yang dapat mempengaruhi tingkat pengetahuan sesorang. Beberapa faktor yang mempengaruhi pengetahuan pada pasien diabetes adalah tingkat pendidikan, usia, pekerjaan, durasi penyakit, dan lingkungan (7). Faktor - faktor yang dapat mempengaruhi tingkat pengetahuan pasien dapat dilihat pada tabel 3.

Tabel 3. Pengaruh Karakteristik Subjek terhadap Pengetahuan Pasien Diabetes Setelah Dilakukan MTM

\begin{tabular}{|c|c|c|c|}
\hline Karakteristik Subjek & $\begin{array}{l}\text { Jumlah Subjek } \\
\qquad(n=25)\end{array}$ & Rata - rata Skor & Nilai $P$ \\
\hline \multicolumn{3}{|l|}{ Tingkat Pendidikan } & \multirow[t]{5}{*}{$0,109^{a}$} \\
\hline $\mathrm{SD}$ & 2 & 12 & \\
\hline SMP & 8 & 10,63 & \\
\hline SMA & 9 & 11,56 & \\
\hline UNIVERSITAS & 6 & 12,67 & \\
\hline \multicolumn{3}{|l|}{ Usia } & \multirow[t]{4}{*}{$0,238^{a}$} \\
\hline $45-54$ tahun & 5 & 11 & \\
\hline $55-64$ tahun & 9 & 12,22 & \\
\hline $65-74$ tahun & 11 & 11,27 & \\
\hline \multicolumn{3}{|l|}{ Pekerjaan } & \multirow[t]{3}{*}{$0,036^{b}$} \\
\hline Kerja & 14 & 11 & \\
\hline Tidak Bekerja & 11 & 12,27 & \\
\hline \multicolumn{3}{|l|}{ Durasi Penykit } & \multirow[t]{5}{*}{$0,913^{\mathrm{a}}$} \\
\hline$<1$ tahun & 5 & 11,40 & \\
\hline $1-10$ tahun & 15 & 11,73 & \\
\hline $11-19$ tahun & 3 & 11,33 & \\
\hline 20 tahun & 2 & 11 & \\
\hline
\end{tabular}

Keterangan: a diuji dengan Kruskal-Wallis test; ${ }^{\mathrm{b}}$ diuji dengan independent sample T-test

Tingkat pendidikan merupakan karakteristik yang berpengaruh terhadap pengetahuan pasien diabetes. Semakin tinggi tingkat pendidikan seseorang maka semakin baik pula pengetahuannya terkait penyakit yang dideritanya dan pengobatan yang digunakannya (22). Pada tabel 3 dapat dilihat bahwa nilai $p$ tingkat pendidikan yang didapatkan adalah $0,109(\mathrm{p}>0,05)$ atau tidak ada perbedaan secara bermakna pada tiap - tiap kelompok tingkat pendidikan. Hanya saja berdasarkan hasil penelitian yang didapatkan dapat dilihat bahwa kelompok dengan tingkat pendidikan hingga Universitas memiliki skor median tertinggi yaitu 13. Tidak adanya perbedaan secara bermakna pada tiap - tiap kelompok dimungkinkan karena durasi penelitian yang cukup singkat. Hal ini didukung dengan penelitian Keban dkk., tahun 2013 terhadap 40 pasien diabetes di RS Dr. 
Sardjito yang hanya melibatkan pasien dengan tingkat pendidikan SMA dan Universitas. Pada penelitian tersebut pasien yang diberikan edukasi selama 3 bulan mengalami perubahan pengetahuan terkait pengobatan diabetes yang digunakan secara bermakna (22). Pada penelitian ini faktor usia tidak terbukti berpengaruh terhadap pengetahuan pasien. Hal ini dapat dilihat pada tabel 3 , nilai $\mathrm{p}$ yang didapatkan adalah 0,238 ( $p>0,05)$ atau tidak ada perbedaan bermakna pada tiap tiap kelompok usia. Hasil ini bertolak belakang dengan penelitian Al-Qazaz dkk., tahun 2011 terhadap 505 pasien diabetes. Pada penelitian tersebut didapatkan perbedaan tingkat pengetahuan pada tiap - tiap kelompok usia dengan nilai $\mathrm{p}=$ 0,005 ( $\mathrm{p}<0,05$ ). Pada penelitiannya Al-Qazaz dkk., tahun 2011 juga menemukan bahwa pasien dengan usia $<65$ tahun memiliki nilai median pengetahuan yang lebih tinggi. Sebaran usia yang ada pada penelitiannya adalah 390 pasien berusia $<65$ tahun dan 115 pasien berusia $>65$ tahun. Lebih banyaknya pasien yang berusia $<65$ tahun ini memungkinkan adanya perbedaan secara bermakna (23). Dibandingkan dengan penelitian ini yang sebaran datanya tidak jauh berbeda antara pasien yang berusia $<65$ tahun (14 pasien) dan pasien yang berusia $>65$ tahun (11 pasien).

Pada penelitian ini faktor pekerjaan terbukti berpengaruh terhadap pengetahuan pasien. Hal ini dapat dilihat dari nilai $\mathrm{p}$ yang didapatkan adalah 0,036 $(\mathrm{p}<0,05)$ atau ada perbedaan bermakna pada tiap - tiap kelompok pekerjaan. Hasil ini sejalan dengan penelitian Fenwick dkk., tahun 2013 terhadap 181 pasien diabetes. Pada penelitian tersebut didapatkan perbedaan tingkat pengetahuan pada tiap - tiap kelompok pekerjaan dengan nilai $p=0,001(p<0,05)$. Pada penelitian ini faktor durasi penyakit tidak terbukti berpengaruh terhadap pengetahuan pasien. Hal ini dapat dilihat dari nilai $p$ yang didapatkan adalah $0,913(\mathrm{p}>0,05)$ atau tidak ada perbedaan bermakna pada tiap - tiap kelompok usia. Hasil ini sejalan dengan penelitian Al-Qazaz dkk., tahun 2011 terhadap 505 pasien diabetes. Pada penelitian tersebut tidak terdapat perbedaan tingkat pengetahuan pada tiap - tiap kelompok durasi penyakit dengan nilai $p=0,140(p>0,05)(23)$. Hal ini membuktikan bahwa lamanya seseorang menderita suatu penyakit tidak ada kaitannya dengan tingkat pengetahuannya. Oleh karena itu pasien harus selalu diberikan edukasi dan diajak untuk berperan aktif terhadap terapi yang dijalaninya. Salah satu intervensi yang dapat diberikan adalah pelayanan MTM. Sebab pelayanan MTM melibatkan peran aktif pasien dalam mengelola kesehatannya sendiri dan membantu profesional kesehatan berkoordinasi dengan baik dalam menangani pasien.

\subsection{Pengaruh Pelayanan Berbasis MTM terhadap Kualitas Hidup}

Kualitas hidup merupakan salah satu variabel yang diukur dalam penelitian ini. Dilakukannya pelayanan berbasis MTM ini diharapkan dapat mengoptimalkan terapi yang diterima oleh pasien, sehingga terjadi peningkatan kualitas hidup. Pengukuran kualitas hidup dengan kuesioner DQOL akan menggambarkan pengaruh pemberian MTM terhadap kualitas hidup pasien. Hasil dari pengukuran pengaruh pemberian MTM terhadap kualitas hidup pasien dapat dilihat pada tabel 4. 
Pada tabel 4 dapat dilihat bahwa pelayanan berbasis MTM dapat meningkatkan kualitas hidup pasien diabetes. Berdasarkan hasil yang didapatkan rata - rata skor sebelum diberikan intervensi adalah 50,56 \pm 3,9 dan setelah diberikan intervensi meningkat menjadi 52,84 $\pm 4,3$. Berdasarkan nilai $p=0,003(p$ $<0,05)$ kedua nilai tersebut berbeda secara bermakna. Hal ini sejalan dengan penelitian Pinto et al., tahun 2014 terhadap 101 pasien diabetes. Pada penelitiannya terjadi perbaikan nilai kualitas hidup setelah diberikan pelayanan berbasis MTM (8). Adanya penerapan pelayanan berbasis MTM oleh apoteker dalam penelitian ini terbukti mampu meningkatkan kualitas hidup pasien karena adanya optimalisasi terapi.

Tabel 4. Pengaruh MTM terhadap Kualitas Hidup Pasien Diabetes Melitus

\begin{tabular}{|l|c|c|c|}
\multicolumn{1}{|c|}{\begin{tabular}{c} 
Kategori \\
\multicolumn{1}{|c|}{ Kualitas Hidup }
\end{tabular}} & $\begin{array}{c}\text { Rata - Rata } \\
\text { Skor } \pm \text { SD }\end{array}$ & Nilai P \\
\hline Pretest & 25 & $50,56 \pm 3,9$ & 0,003 \\
\hline Postest & 25 & $52,84 \pm 4,3$ & \\
\hline
\end{tabular}

Keterangan: *diuji dengan Wilcoxon test

Kualitas hidup merupakan suatu konsep yang secara kompleks dipengaruhi oleh kesehatan fisik, keadaan psikologis, kepercayaan pribadi, hubungan sosial, dan lingkungan pasien. Faktor lain yang dapat mempengaruhi kualitas hidup pasien diabetes adalah usia, jenis kelamin, tingkat pendidikan, pekerjaan, dan pendapatan (24). Pada penelitian ini peneliti meninjau hubungan antara usia, jenis kelamin, tingkat pendidikan, pekerjaan, penyakit penyerta dan durasi penyakit terhadap kualitas hidup pasien diabetes. Hubungan faktor - faktor tersebut terhadap kualitas hidup pasien dapat dilihat pada tabel 5 . Pasien diabetes berusia lanjut biasanya mengalami sindrom geriatri dan kejadian hipoglikemia. Hal tersebut dapat mempengaruhi kualitas hidup dari pasien. Pada penelitian ini adanya perbedaan usia tidak terbukti mempengaruhi kualitas hidup pasien diabetes. Hal ini dibuktikan dengan nilai $p=0,736(p>0,05)$. Secara statistik tidak ada perbedaan bermakna kualitas hidup pada tiap - tiap kelompok usia. Hasil ini bertolak belakang dengan penelitian Rodriguez et al., tahun 2018 terhadap pasien diabetes dengan nilai $\mathrm{p}=$ $0,001(\mathrm{p}<0,05)(24)$. Hasil penelitian ini sejalan dengan penelitian Hasina dkk., tahun 2014 yang juga menemukan bahwa faktor usia tidak berpengaruh terhadap kualitas hidup pasien (25).

Berdasarkan penelitian Rodriguez et al., tahun 2018 terhadap pasien diabetes ditemukan bahwa jenis kelamin berpengaruh terhadap kualitas hidup. Hasil ini ditunjukkan dengan nilai $\mathrm{p}<0,001(\mathrm{p}<0,05)$, atau ada perbedaan bermakna pada tiap - tiap kelompok jenis kelamin (24). Hanya saja hal tersebut tidak terbukti dalam penelitian ini yang dibuktikan dengan nilai $p=0,923(p>0,05)$. Pada penelitian ini adanya perbedaan tingkat pendidikan tidak terbukti mempengaruhi kualitas hidup pasien diabetes. Hal ini dibuktikan dengan nilai $\mathrm{p}=$ $0,197(p>0,05)$ atau secara statistik tidak ada perbedaan bermakna. Hasil ini sejalan dengan penelitian Rodriguez et al., tahun 2018 terhadap pasien diabetes dengan nilai $p=0,232(p>0,05)$. Hasil ini membuktikan bahwa tinggi rendahnya 
tingkat Pendidikan tidak ada hubungannya dengan kualitas hidup pasien diabetes (24). Pada penelitian ini adanya perbedaan status pekerjaan tidak terbukti mempengaruhi kualitas hidup pasien diabetes. Hal ini dibuktikan dengan nilai $\mathrm{p}=$ 0,457 ( $p>0,05$ ) atau secara statistik tidak ada perbedaan bermakna. Hasil ini bertolak belakang dengan penelitian Chyun et al., tahun 2006 terhadap pasien diabetes. Penelitian tersebut menemukan bahwa pasien yang tidak bekerja memiliki nilai kualitas hidup yang lebih rendah secara signifikan. Tidak memiliki pekerjaan merupakan stressor yang umum dan merupakan faktor risiko dari penurunan kesehatan (26).

Tabel 5. Pengaruh Karakteristik Subjek terhadap Kualitas Hidup Pasien Diabetes Setelah Dilakukan MTM

\begin{tabular}{|c|c|c|c|}
\hline Karakteristik Subjek & $\begin{array}{l}\text { Jumlah Subjek } \\
\qquad(n=25)\end{array}$ & Rata-rata Skor & Nilai P \\
\hline Usia & & & \multirow[t]{4}{*}{$0,736^{\mathrm{a}}$} \\
\hline $45-54$ tahun & 5 & 52,60 & \\
\hline $55-64$ tahun & 9 & 53,11 & \\
\hline $65-74$ tahun & 11 & 52,45 & \\
\hline \multicolumn{3}{|l|}{ Jenis Kelamin } & \multirow[t]{3}{*}{$0,923 \mathrm{~b}$} \\
\hline Laki - Laki & 13 & 52,92 & \\
\hline Perempuan & 12 & 52,75 & \\
\hline \multicolumn{3}{|l|}{ Tingkat Pendidikan } & \multirow[t]{5}{*}{$0,197^{a}$} \\
\hline SD & 2 & 52,50 & \\
\hline SMP & 8 & 54,38 & \\
\hline SMA & 9 & 53,56 & \\
\hline UNIVERSITAS & 6 & 49,33 & \\
\hline \multicolumn{3}{|l|}{ Pekerjaan } & \multirow[t]{3}{*}{$0,457^{b}$} \\
\hline Bekerja & 14 & 53,57 & \\
\hline Tidak Bekerja & 11 & 51,91 & \\
\hline \multicolumn{3}{|l|}{ Penyakit Penyerta } & \multirow[t]{5}{*}{$0,095^{a}$} \\
\hline Hipertensi & 13 & 51,77 & \\
\hline Hiperlipidemia & 4 & 51 & \\
\hline Hipertensi + Hiperlipidemia & 2 & 56 & \\
\hline Tanpa Penyakit Penyerta & 6 & 54,83 & \\
\hline \multicolumn{3}{|l|}{ Durasi Penyakit } & \multirow[t]{5}{*}{$0,535^{a}$} \\
\hline$<1$ tahun & 5 & 53,60 & \\
\hline $1-10$ tahun & 15 & 51,80 & \\
\hline 11- 20 tahun & 3 & 54 & \\
\hline$>20$ tahun & 2 & 55,50 & \\
\hline
\end{tabular}

Keterangan: a diuji dengan Kruskal-Wallis test; ${ }^{\mathrm{b}}$ diuji dengan independent sample T-test

Pada penelitian ini adanya perbedaan penyakit penyerta tidak terbukti mempengaruhi kualitas hidup pasien diabetes. Hal ini dibuktikan dengan nilai $\mathrm{p}=$ $0,095(\mathrm{p}>0,05)$ atau secara statistik tidak ada perbedaan bermakna. Hal serupa ditemukan pada penelitian Redekop et al., tahun 2002 bahwa penyakit penyerta hipertensi dan hiperlipidemia tidak berpengaruh terhadap kualitas hidup pasien diabetes. Berdasarkan nilai $\mathrm{p}$ yang didapatkannya untuk penyakit penyerta hipertensi $p=0,4773(p>0,05)$ dan penyakit penyerta hiperlipidemia $p=0,4712(p$ $>0,05)(27)$. Penelitian Redekop et al., tahun 2002 juga menemukan bahwa durasi 
penyakit dapat mempengaruhi kualitas hidup pasien dengan nilai $\mathrm{p}<0,001$ ( $\mathrm{p}<$ $0,05)$. Tetapi pada penelitian ini tidak ditemukan adanya perbedaan kualitas hidup berdasarkan durasi penyakit. Hal ini dibuktikan dengan nilai $p=0,535(p>0,05)$ atau secara statistik tidak ada perbedaan bermakna. Pada penelitiannya juga ditemukan bahwa pasien dengan durasi penyakit $>10$ tahun memiliki nilai kualitas hidup yang lebih rendah. Durasi penyakit yang semakin lama memungkinkan adanya komplikasi yang dialami oleh pasien. Komplikasi ini dapat memperburuk kondisi pasien yang pada akhirnya akan mempengaruhi persepsi pasien akan kondisi serta kualitas hidupnya (27). Pada tabel 5 juga dapat dilihat bahwa pasien yang ikut serta dalam penelitian ini mayoritas memiliki durasi penyakit $\leq 10$ tahun. Hal ini yang mungkin menyebabkan tidak adanya perbedaan kualitas hidup pada tiap - tiap kelompok durasi penyakit.

\section{KESIMPULAN}

Pelayanan berbasis Medication Therapy Management yang dilakukan oleh Apoteker dapat meningkatkan pengetahuan pasien diabetes secara bermakna $(\mathrm{p}=$ $0,000)$ dan meningkatkan kualitas hidup pasien diabetes secara bermakna $(\mathrm{p}=$ $0,003)$.

\section{UCAPAN TERIMAKASIH}

Penulis mengucapkan terima kasih kepada pihak Puskesmas, Responden, serta berbagai pihak yang telah banyak membantu melancarkan proses penelitian ini.

\section{DAFTAR PUSTAKA}

[1]. Alldredge BK, Affairs A, Francisco S, Francisco S, Corelli RL, Francisco S, et al. Applied therapeutics: The clinical use of drugs. Tenth. Troy DB, editor. Comparative Biochemistry and Physiology Part A: Physiology. Philadelphia: Wolters Kluwer/ Lippincott Williams \& Wilkins; 2013.

[2]. Chisholm-Burns MA, Schwinghammer TL, Wells BG, Malone PM, Kolesar JM, DiPiro JT. Pharmacotherapy Principles \& Practice. Fourth. United State: Mc Graw Hill Education; 2016.

[3]. WHO. Diabetes [Internet]. 2019. Available from: https://www.who.int/news-room/fact-sheets/detail/diabetes

[4]. WHO. Proportional mortality (\% of total deaths, all ages). World Heal Organ [Internet]. 2016;1. Available from: https://www.who.int/diabetes/countryprofiles/bra_en.pdf

[5]. Kementerian Kesehatan RI Badan Penelitian dan Pengembangan. Hasil Utama Riset Kesehatan Dasar. Kementrian Kesehat Republik Indones [Internet]. 2018;1-100. Available from: http://www.depkes.go.id/resources/download/info-terkini/hasilriskesdas-2018.pdf

[6]. Septiar HE, Utami P. Pengaruh Konseling Farmasis Terhadap Kualitas Hidup Dan Kadar Gula Darah Pada Pasien Diabetes Mellitus Tipe 2 Di Puskesmas 
Gedong Tengen Periode Maret-Mei 2014. FJurnal Farm Sains dan Prakt [Internet]. 2015;1(1):29-34. Available from: http://repository.umy.ac.id/handle/123456789/1989

[7]. Fenwick EK, Xie J, Rees G, Finger RP, Lamoureux EL. Factors associated with knowledge of diabetes in patients with type 2 diabetes using the diabetes knowledge test validated with Rasch analysis. PLoS One. 2013;8(12):8-14.

[8]. Pinto SL, Kumar J, Partha G, Bechtol R a. Pharmacist-provided Medication Therapy Management (MTM) program impacts outcomes for employees with diabetes. Popul Health Manag. 2014;17(1):21-7.

[9]. Bluml BM. Definition of medication therapy management: Development of professionwide consensus. J Am Pharm Assoc [Internet]. 2005;45(5):56672. Available from: http://dx.doi.org/10.1331/1544345055001274

[10]. Al-Tameemi NK, Sarriff A. Knowledge, attitude and practice of pharmacists on medication therapy management: a survey in Hospital Pulau Pinang, Penang, Malaysia. J Pharm Heal Care Sci. 2019;5(1):1-9.

[11]. Burns A. Medication therapy management in pharmacy practice: Core elements of an MTM service model (version 2.0). J Am Pharm Assoc [Internet]. 2008;48(3):341-53. Available from: http://dx.doi.org/10.1331/JAPhA.2008.08514

[12]. Lemay G. Medication therapy management in community pharmacy practice. Med Health R I. 2012;95(9):281-2.

[13]. Lounsbery JL, Green CG, Bennett MS, Pedersen C a. Evaluation of pharmacists' barriers to the implementation of medication therapy management services. J Am Pharm Assoc [Internet]. 2009;49(1):51-8. Available from: http://dx.doi.org/10.1331/JAPhA.2009.07158

[14]. Collins GS, Mughal S, Barnett a. H, Fitzgerald J, Lloyd CE. Modification and validation of the Revised Diabetes Knowledge Scale. Diabet Med. 2011;28(3):306-10.

[15]. Fitzgerald JT, Funnell MM, Anderson RM, Nwankwo R, Stansfield RB, Piatt G a. Validation of the Revised Brief Diabetes Knowledge Test (DKT2). Diabetes Educ. 2016;42(2):178-87.

[16]. Bujang MA, Adnan TH, Mohd Hatta NKB, Ismail M, Lim CJ. A Revised Version of Diabetes Quality of Life Instrument Maintaining Domains for Satisfaction, Impact, and Worry. J Diabetes Res. 2018;2018(July):5804687.

[17]. American Diabetes Association. Diabetes Care: Standards of Medical Care in Diabetes-2019. J Clin Appl Res Educ. 2019;42(1):204.

[18]. Dipiro JT, Talbert RL, Yee GC, Matzke GR, Wells BG, Posey LM. Pharmacotherapy A Pathophysiologic Approach. 2017;6513.

[19]. Rosyada A, Trihandini I. Determinan Komplikasi Kronik Diabetes Melitus pada Lanjut Usia Determinan of Diabetes Mellitus Chronic Complications on Elderly. J Kesehat Masy Nas. 2013;7:395-401.

[20]. Ndefo UA, Moultry AM, Davis PN, Askew R. Provision of medication therapy management by pharmacists to patients with type- 2 diabetes mellitus in a federally qualified health center. P T [Internet]. 2017;42(10):632-7. 
Available

from: https://www.ncbi.nlm.nih.gov/pmc/articles/PMC5614414/pdf/ptj421063 2.pdf

[21]. Boban B, Aswathy KS, Athira BM, Karthikeyan M, Xavier A, Aravind RS. Impact of medication therapy management on knowledge, attitude and practice among diabetic patients. Clin Epidemiol Glob Heal [Internet]. 2017;5(2):70-2. Available

from: http://dx.doi.org/10.1016/j.cegh.2016.11.002

[22]. Keban SA, Purnomo LB. Evaluasi Hasil Edukasi Farmasis Pada Pasien Diabetes Melitus Tipe 2 Di Rumah Sakit Dr. Sardjito Yogyakarta. 2013 Apr;8.

[23]. Al-Qazaz HK, Sulaiman S a., Hassali M a., Shafie A a., Sundram S, Al-Nuri R, et al. Diabetes knowledge, medication adherence and glycemic control among patients with type 2 diabetes. Int J Clin Pharm. 2011;33(6):1028-35.

[24]. Rodríguez-Almagro J, García-Manzanares Á, Lucendo AJ, HernándezMartínez A. Health-related quality of life in diabetes mellitus and its social, demographic and clinical determinants: A nationwide cross-sectional survey. J Clin Nurs. 2018;27(21-22):4212-23.

[25]. Hasina R, Probosuseno, Wiedyaningsih C. Hubungan Tingkat Kepatuhan, Kepuasan Terapi Dengan Kualitas Hidup Pasien Usia Lanjut Diabetes Melitus Tipe 2. J Manaj dan Pelayanan Farm. 2014;4(4):251-6.

[26]. Chyun DA, Melkus GD, Katten DM, Price WJ, Davey JA, Grey N, et al. The Association of Psychological Factors , Physical Activity, Neuropathy, and Quality of Life in Type 2 Diabetes. 2006;(203).

[27]. Redekop WK, Koopmanschap MA, Stolk RP, Rutten GEHM, Wolffenbuttel BHR, Niessen LW. Health-Related Quality of Life and Treatment Satisfaction in Dutch Patients With Type 2 Diabetes METHODS. Diabetes Care. $2002 ; 25(3)$. 